\title{
Design a Low-Cost Digital Pressure Meter Equipped with Temperature and Humidity Parameters
}

\author{
Bedjo Utomo $^{1}$, I Dewa Gede Hariwisana ${ }^{1}$, Shubhrojit Misra ${ }^{2}$ \\ ${ }^{1}$ Departemen Electromedical Teknik Poltekkes Kemenkes, Surabaya, Indonesia \\ Jl. Pucang Jajar Timur No. 10, Surabaya, 60245, Indonesia \\ ${ }^{2}$ Department of Electronics and Telecommunication Engineering, Jadavpur University \\ 188, Raja S.C. Mallick Rd, Kolkata, West Bengal 700032, India
}

\section{Article Information \\ Article History: \\ Received: April 5, 2021 \\ Revision: April 15,2021 \\ Accepted: May 10, 2021}

Keyword:
Calibration
Pressure meter
Sphygmomanometer
Humidity

\section{Corresponding author:}

bedjoutomo123@gmail.com

Departemen Electromedical Teknik

PoltekkesKemenkes, Surabaya

Jl. Pucang Jajar Timur No. 10, Surabaya, 60245, Indonesia

\begin{abstract}
Abstrak
Calibration is a technical activity which consists of determining one or more properties and characteristics of a product, process or service according to a predetermined special procedure. The purpose of calibration is to ensure measurement results comply with national and international standards. The purpose of this study is to design two mode digital pressure meter (DPM) device equipped with a thermo-hygrometer and pressure in which the design is completed with a selection mode to determine the positive and negative pressure (vacuum) using MPX 5050GP sensor as a positive pressure sensor. In this design DHT 22 sensors is used to measure the humidity and temperature. To test the leak test this device is also equipped with timer. This design uses a 2.4 inch Nextion TFT LCD screen to display data. Data analysis was performed by comparing modul with standard tools. In the measurement process, Mercury tensimeter was carried out 6 times the data and the smallest results were $0 \mathrm{mmHg}$ on the module and $0 \mathrm{mmHg}$ on the standard tool and the largest was $298.0 \mathrm{mmHg}$ on the module and $300 \mathrm{mmHg}$ on the standard tool. Data were collected in a room with a temperature of $31^{\circ} \mathrm{C}$ and humidity of $\mathbf{8 7 \%}$. Finally, this design is applicable for daily used for electromedical engineer to calibrate the sphygmomanometer in the hospitals.
\end{abstract}

This work is an open access article and licensed under a Creative Commons Attribution-ShareAlike 4.0 International License(CC BY-SA 4.0).

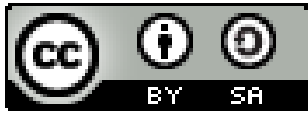

\section{INTRODUCTION}

Digital Pressure Meter (DPM) is a tool used to measure positive and negative pressure on medical devices in liquid or gas form to assist in quality improvement and control. The way this tool works is by converting the value of the pressure sensor to be changed and displayed on the display. There are many forms, types, and functions of Digital Pressure Meter, such as those that serve only as inflatable pressure and suction pressure. In this study, the use of DPM related to calibration on mercury tensimeters and suction pumps. Tensimeter is a tool to measure blood pressure that is often used in the medical world, its function is vital because it becomes the basis for doctors to diagnose patient health.[1]

Accurate blood pressure measurement requires the use of an accurate sphygmomanometer. The accuracy of the sphygmomanometer relies heavily on performing the correct maintenance and calibration process of this equipment. One of the most common errors in blood pressure measurement is caused by the use of an uncalibrated sphygmomanometer and improper use of cuffs. Inaccurate maintenance and calibration of sphygmomanometers is the cause of systematic errors in blood pressure measurement.

Tensimeter is a tool that has a low and high risk, judging by its use tensimeter is a tool that is often used continuously so that the risk of a decrease in tool performance is very high let alone never done good maintenance. frequent damage that is at the level of leakage. Several measuring instruments tensimeters and suction pumps have been made electromedical engineering students titled DPM Two Modes Equipped With Temperature And Humidity Portable Based Arduino Nano. [2] On the tool is made 2 modes of waiting for temperature and humidity by displayed on the character LCD. Furthermore, in $2017 \mathrm{~N} \mathrm{H}$ Zunnur analyzed the suitability of mercury and digital tensimeter types to blood pressure measurements in adulthood in the analysis stated that the difference between the two tensimeters was indicated by good conformity tests, namely systolic pressure (Kappa Value $=0.782$ ) and Distolic pressure (Kappa value=0.565) [3]. In 2017 by Junia Dyah Permata Wibisono made the final task with the title Digital Pressure 


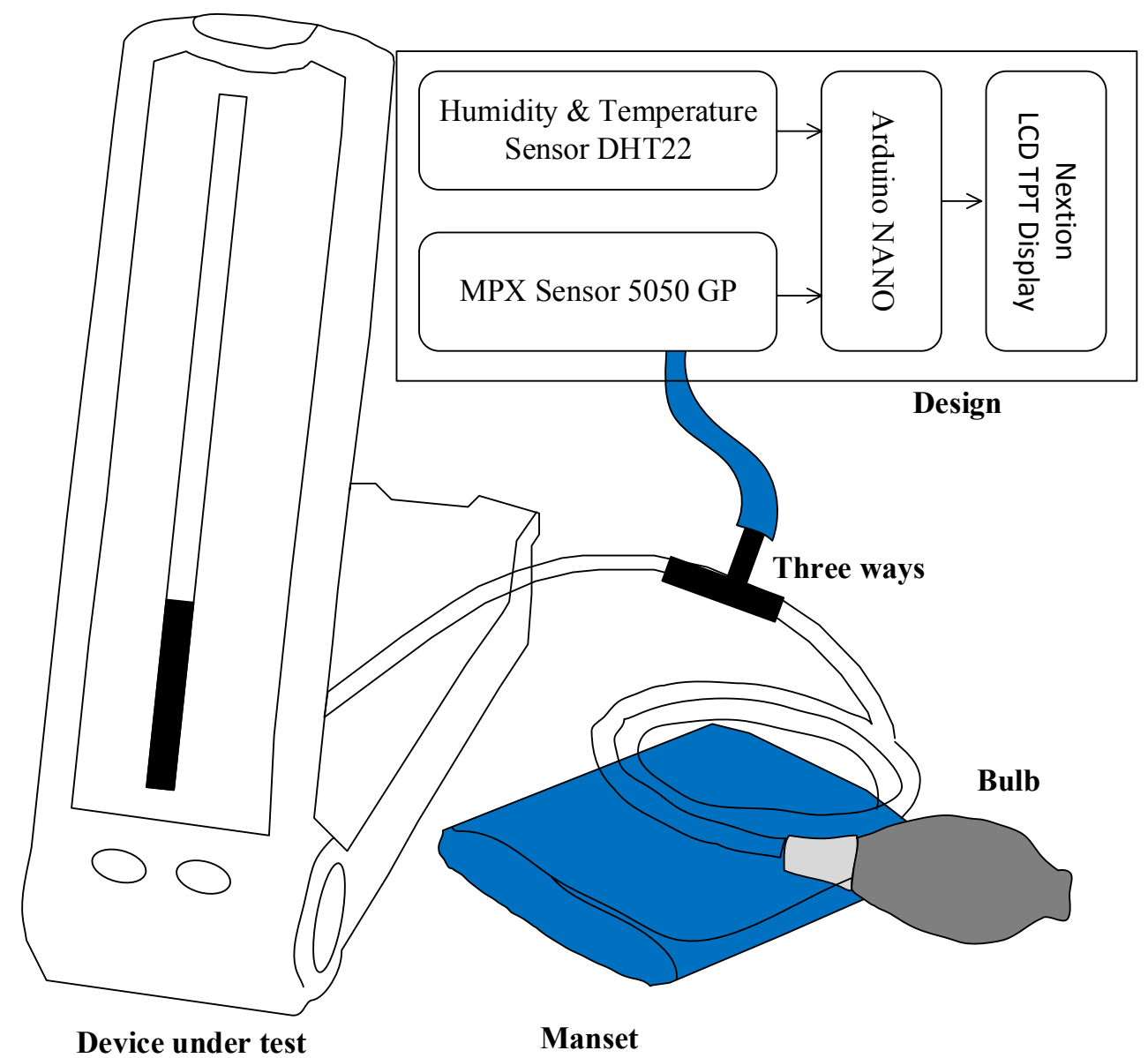

Fig. 1 The diagram block of the system

Meter (DPM) Vacum Pressure with lcd display characters. In this tool only use 1 (one) mode that is used only for suction pump [3] and In 2018 Yosep Kurniawan made the final task of Digital Pressure Meter (DPM) two modes namely positive pressure and suction pressure but this tool is still relatively standard accuracy level that has a correction value of 0 $3 \mathrm{mmHg}$ [4]. Furthermore, in 2019 Mukhamad Ryan Nur Rohman in a study on the design entitled Digital Pressure Meter (DPM) Tensimeter and Suction Pump, but this tool still has a deficiency in the measurement of the rate of leakage tensimeter is not equipped with the temperature and humidity of the room, this is very important because the temperature, and humidity of the room can affect the results at the time of measurement. [4]

Calibration environmental conditions should be adjusted according to the requirements of calibration methods such as temperature and humidity. [5] Not always calibration should be done in a tightly conditioned room. Calibration environmental conditioning is usually done for calibration of volatile equipment due to the influence of temperature, humidity, vibration, light, and so on. [6].

\section{MATERIALS AND METHODS}

\section{A. Research Design}

This study used measurements against mercury tensimeters with positive pressure settings; $0 \mathrm{mmHg}, 50 \mathrm{mmHg}, 100 \mathrm{mmHg}$, $150 \mathrm{mmHg}, 200 \mathrm{mmHg}, 250 \mathrm{mmHg}, 300 \mathrm{mmHg}$, which can then be converted to $\mathrm{kPa}$. Data retrieval repeated 6 times. [7]

\section{1) Materials}

This study used the MPX 5050GP Sensor by Freescale Semiconductor to serve as an inflatable pressure. And the DHT22 Aosong Electronics Co.,Ltd sensor serves as a temperature, humidity sensor. Output sensor MPX 5050 GP then go to the input buffer circuit. The output of the buffer circuit then VCC, output and GND from the DHT 22 sensor legs then enter and be processed into the Arduino Nano. Arduino Nano as controller and controller. Arduino Nano output in the form of a display on the 2.4 inch TFT Nextion $\mathrm{LCD}[8][6]$.

\section{2) Experiments}

In this study, after the finished design, digital pressure meter (Positive Pressure) output testing was conducted with pressures of $0 \mathrm{mmHg}, 50 \mathrm{mmHg}, 100 \mathrm{mmHg}, 150 \mathrm{mmHg}, 200 \mathrm{mmHg}$, 
$250 \mathrm{mmHg}, 300 \mathrm{mmHg}$, and measurements with the Tensimeter. Each setting, calculated to validate the results of this study.

\section{B. Block Diagram}

In this study, Positive data was obtained from cuff hoses and pump hoses from Tensimeters with several pressures namely 0 $\mathrm{mmHg}, 50 \mathrm{mmHg}, 100 \mathrm{mmHg}, 150 \mathrm{mmHg}, 200 \mathrm{mmHg}, 250$ $\mathrm{mmHg}, 300 \mathrm{mmHg}$, shown in Figure. 1. MPX 5050 GP sensor as inflatable pressure. The sensor output then enters the buffer circuit input as a current amplifier without voltage amplifier occurring. The output buffer is then entered and processed into Arduino Nano. There is a conversion from $\mathrm{mmHg}$ to $\mathrm{kPa}$ to be processed to Arduino Nano as well. After processing using Arduino Nano, the output is a display on the 2.4 inch TFT Nextion LCD. [9] In Fig. 1 Blog Diagrams it is explained that in the calibration process, the cuff hose and pump hose of the tensimeters used for calibration testing materials. MPX 5050 GP sensor as an inflatable pressure sensor. Output sensor further into the DHT 22 sensor as a humidity temperature sensor, VCC, output and ground are connected to the Arduino nano pin.[10] [11] then conduct a test for 60 seconds that serves as a time to perform a leak test when performing measurements on the tensimeter. Furthermore, the data displayed on the 2.4inch TFT Nextion LCD serves as a display to display the measurement, calibration process. On the Digital Pressure Meter tool system, the LCD displays the result of pressure and conversion.

\section{Flowchart}

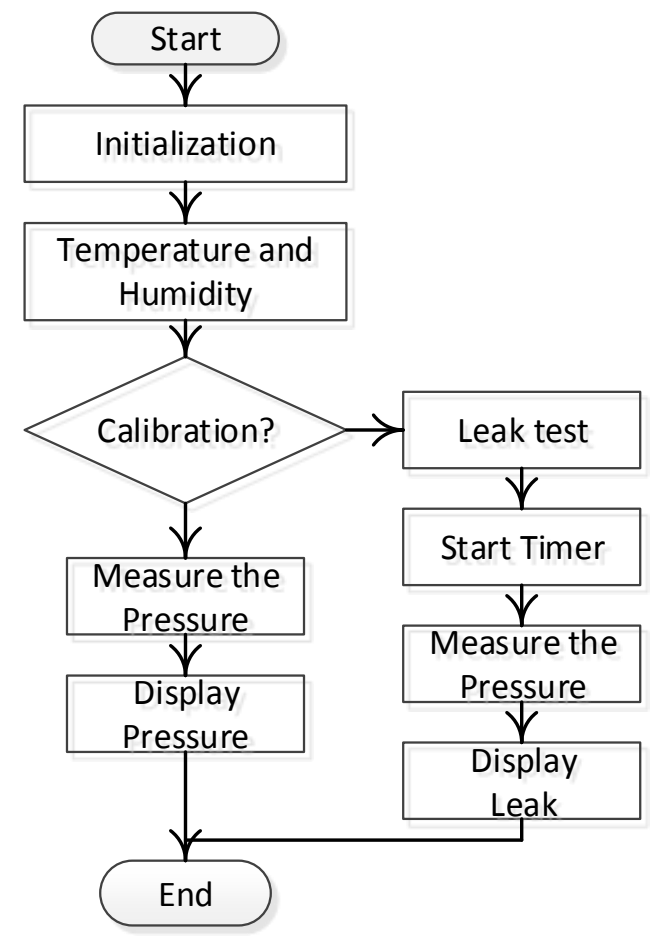

Fig. 2 The system flowchart
In figure 2 flow diagram starts when the module starts then there is initialization, there is the appearance of temperature, humidity, there are two modes of selection, namely positive mode and vacuum, when choosing a positive mode when doing manual pumping then the MPX 5050 GP sensor will read and the results will be displayed in positive mode measurement there is a 60 -second timer for leak test. From the reading can be converted again pressure unit from $\mathrm{mmHg}$ to $\mathrm{kPa}$ and then the data is displayed on the LCD TFT Nextion 2.4 inch.

\section{RESULTS}

In this study, Digital Pressure Meter Module has been measured with Mercury Tensimeter tool

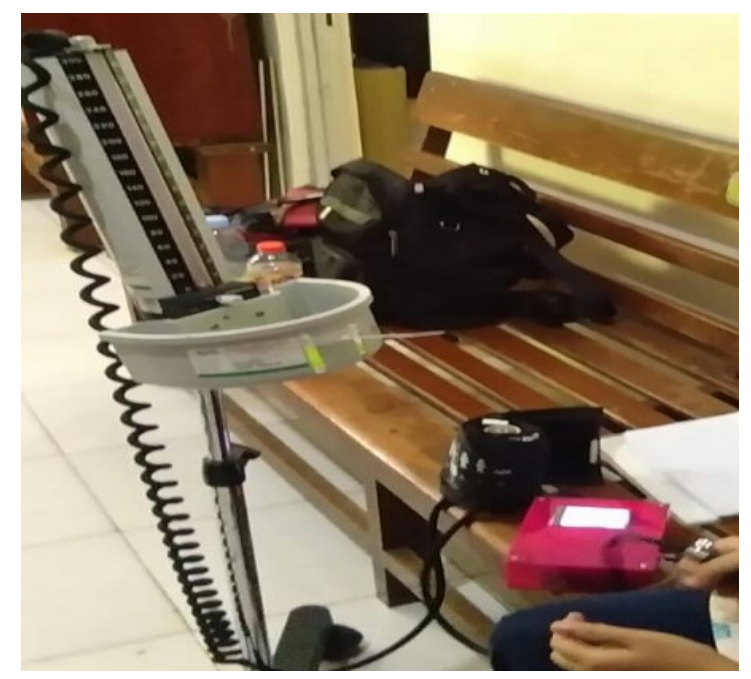

Fig.3 Pengukuran pada tensimeter

In fiq. 3 The Digital Pressure Meter module contains each connector of the maximum pressure sensor output of the vacuum pressure of $-400 \mathrm{mmHg}$

\section{1) Digital Pressure Meter Module Design \\ Display used using LCD TFT Nextion fiq. 4}

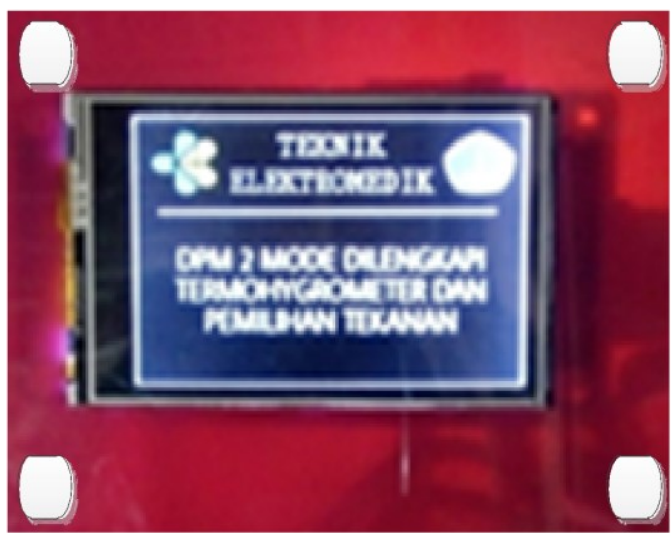

Fig. 4. Digital Pressure Display 

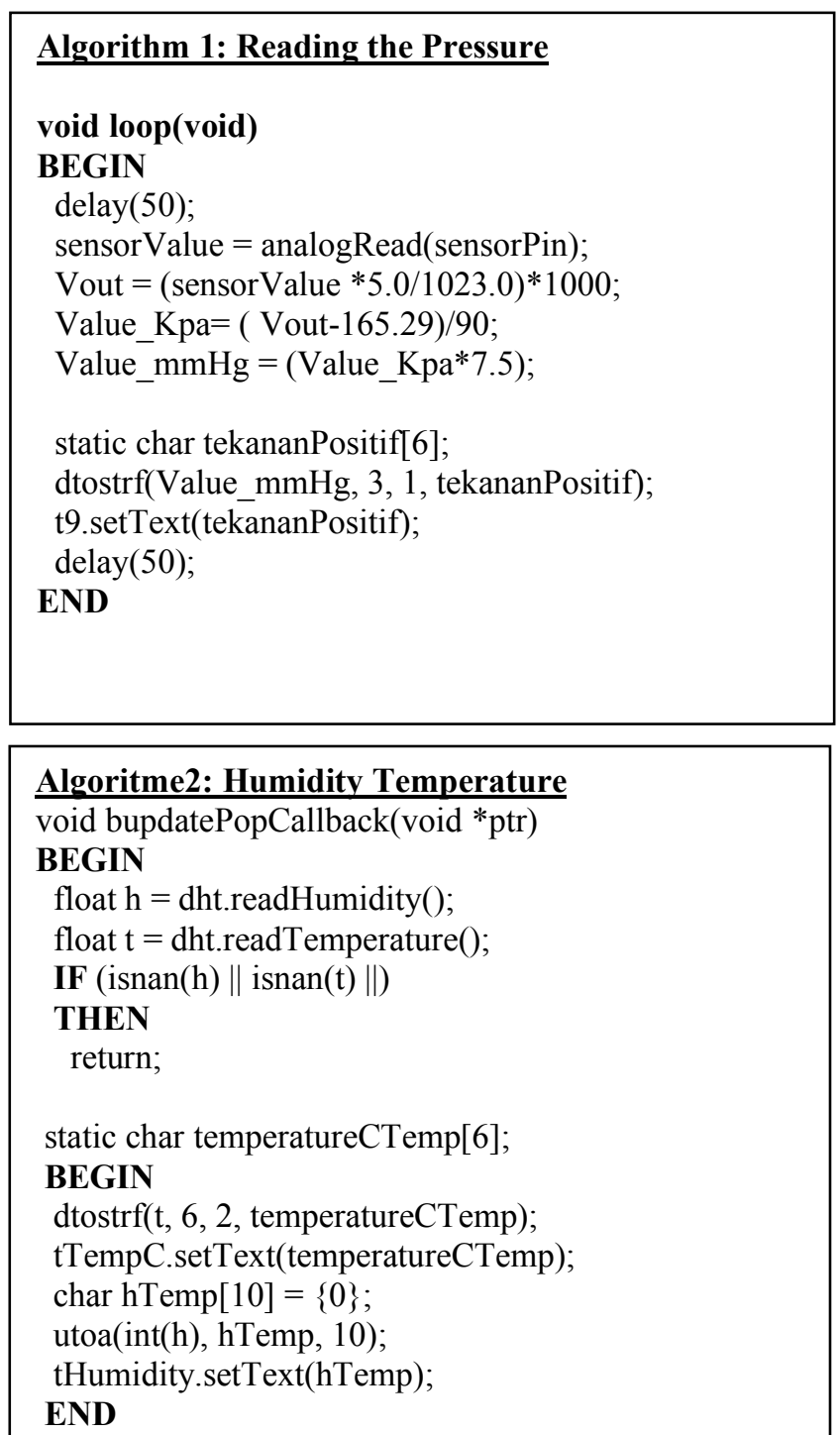

3) Measurement on Mercury Tensimeter

Pressure measurements in the module range from $0 \mathrm{mmHg}$ to $300 \mathrm{mmHg}$ with the pressure measurement range rising per 50 $\mathrm{mmHg}$ performed for $3 \mathrm{x}$ measurements. The results of the analysis can be seen in the table below.

TABLE I. ANOVA SINGLE FACTOR IN MEASUREMENT OF INCREASING MODE

\begin{tabular}{crrrr}
\hline Groups & Count & \multicolumn{1}{c}{ Sum } & Average & Variance \\
\hline Increase 1 & 7 & 1038 & 148,29 & 11504,9 \\
Increase 2 & 7 & 1042 & 148,86 & 11386,5 \\
Increase 3 & 7 & 1046 & 149,43 & 11534,6 \\
\hline
\end{tabular}

TABLE II. ANOVA PARAMETER FOR SIGNIFICANT DIFFERENCE BETWEEN MEASUREMENT

\begin{tabular}{lccccc}
\hline $\begin{array}{l}\text { Source of } \\
\text { Variation }\end{array}$ & SS & MS & F & P-value & F crit \\
\hline Between & & & & & \\
Groups & 4,5714 & 2,28571 & 0,00019 & 0,9998 & 3,555 \\
Within & & & & & \\
Groups & 206556 & 11475,3 & & & \\
Total & 206561 & & & & \\
\hline
\end{tabular}

In table 1 the results of the analysis showed no influence $(p=0.999)$ on measurements made for $3 \mathrm{x}$. Meanwhile, the measurements in the module are carried out from $0 \mathrm{mmHg}$ to $300 \mathrm{mmHg}$ can be seen in table II.

TABLE III THE VARIANCE CALCULATION AMONG MEASUREMENT

\begin{tabular}{crrrr}
\hline Groups & Count & \multicolumn{1}{c}{ Sum } & \multicolumn{1}{c}{ Average } & Variance \\
\hline Down 1 & 7 & 1036 & 148 & 11452,7 \\
Down 2 & 7 & 1033 & 147,571 & 11518 \\
Down 3 & 7 & 1033 & 147,571 & 11585,3 \\
\hline
\end{tabular}

TABLE IV. ANOVA PARAMETER FOR SIGNIFICANT DIFFERENCE BETWEEN MEASUREMENT

\begin{tabular}{lcccr}
\hline $\begin{array}{l}\text { Source of } \\
\text { Variation }\end{array}$ & SS & F & P-value & F crit \\
\hline Between & & & & \\
Groups & 0,8571 & $3,72 \mathrm{E}-05$ & 0,99996 & 3,55 \\
Within & & & & \\
Groups & 207335 & & & \\
Total & 207336 & & & \\
\hline
\end{tabular}

In table II the analysis showed no influence $(p=0.999)$ as long as the measurements performed on the measurements dropped on the module from $0 \mathrm{mmHg}$ to $300 \mathrm{mmHg}$. 


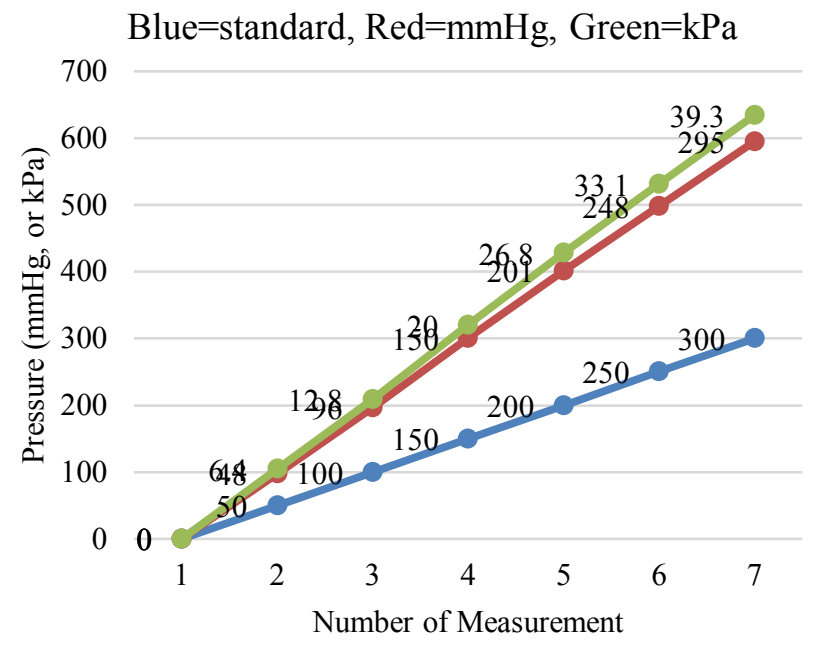

Fig. 8. Convert mmHg Value to Kpa at Up Position

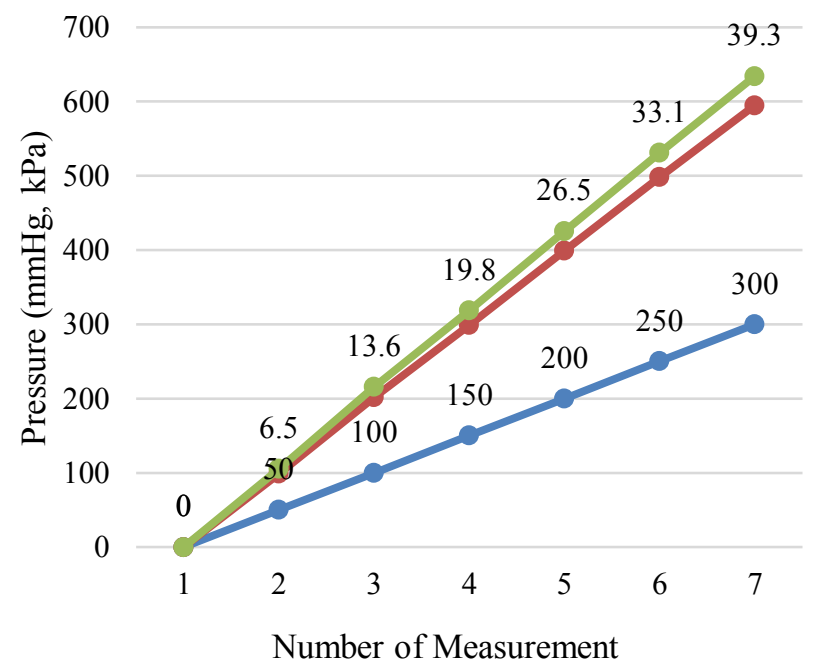

$\longrightarrow$ Meansurement Value $\longrightarrow$ Value mmHg $\longrightarrow$ Value Kpa

Fig. 9. Conversion of mmHg Value to Kpa at down position

Data retrieval in this module is done with a standard mercury tensimeter and this measurement is done for 6 measurements.

\section{DISCUSSION}

Positive pressure measurement of $0-300 \mathrm{mmHg}$ with a $50 \mathrm{mmHg}$ point increase obtained a reduction difference of $3.3>0<3.3$ with an average error factor of $2=0.39$. In negative pressure measurements of $0-300 \mathrm{mmHg}$ with a decrease of $50 \mathrm{mmHg}$ the difference of $-3.7>0<3.7$ with an error factor of rata $2=0.26$, this meets calibration standards for uncertainty factors in measurement errors of 0.8. Measurement of this module is done by retrieving data on the mercury tensimeter tool 6 times. Thus, the results of the design is not much different from standard equipment. The result of moisture temperature measurement is done in the room with the module's humidity temperature parameter obtained room temperature of $25 \mathrm{oC}$ and humidity of $80 \%$. With a difference of $<0.2$ from the standard equipment measurement.

\section{CONCLUSION}

The purpose of this study is to design a complete standard of the digital pressure meter equipped with temperature and humidity parameter. In the design of the DPM Two Modes module equipped thermo-hygrometer and overall pressure selection it was concluded that the Circuit made was in accordance with the needs of the DPM module, namely for ADC, touch screen display button. The result of positive pressure measurement at pressure 0 to $300 \mathrm{mmHg}$ commonly used on mercury tensimeter has an error rate below normal $5 \%$, ie rata $2=0.39$ while at negative pressure rata 2 of 0.26 with module design has met calibration standards. Furthermore, the results of the measurement of temperature and humidity in the module have met the standard of measurement room, namely: temperature $25 \mathrm{oC}$ and inertia by $80 \%$. For the future this design research can be developed in the design towards IoT.

\section{REFERENCE}

[1] A. de Greeff, I. Lorde, A. Wilton, P. Seed, A. J. Coleman, and A. H. Shennan, "Calibration accuracy of hospitalbased non-invasive blood pressure measuring devices," $J$. Hum. Hypertens., vol. 24, no. 1, pp. 58-63, 2010.

[2] D. A. Cholid, Ridwan, "Digital Pressure Meter Equipped with Temperature and Humidity," Indones. J. Electron. Electromed. Eng. Med. informatics, vol. 2, no. 1, pp. 1-5, 2020.

[3] dkk N H Zunnur, "Kesesuaian Tipe Tensimeter Air Raksa Dan Tensimeter Pegas Terhadap Pengukuran Tekanan Darah Pada Usia Dewasa," Diponegoro Med. J. (Jurnal Kedokt. Diponegoro), vol. 6, no. 2, pp. 1208-1216, 2017.

[4] M. R. N. Rokhman, B. G. Irianto, and H. G. Ariswati, "Digital Pressure Meter Tensimeter Dan Suction Pump," J. Teknokes, vol. 12, no. 1, pp. 1-4, 2019.

[5] S. Vatsal and M. Bhavin, "Using Raspberry Pi To Sense Temprature and Relative Humidity," Int. Res. J. Eng. Technol., vol. 4, no. 2, pp. 380-385, 2017.

[6] M. J. Turner, C. Speechly, and N. Bignell, "Sphygmomanometer calibration Why, how and how often?," Aust. Fam. Physician, vol. 36, no. 10, pp. 834 837, 2007.

[7] G. Avendaño, P. Fuentes, V. Castillo, C. Garcia, and N. Dominguez, "Reliability and safety of medical equipment by use of calibration and certification instruments," LATW2010 - 11th Latin-American Test Work., pp. 4-7, 2010.

[8] J. Rosen, M. Brand, M. B. Fuchs, and M. Arcan, "A myosignal-based powered exoskeleton system," IEEE

\section{Accredited by Ministry of Research and Technology /National Research and Innovation Agency, Indonesia} Decree No: 200/M/KPT/2020 
Trans. Syst. Man, Cybern. Part ASystems Humans., vol. 31, no. 3, pp. 210-222, 2001.

[9] E. O'Brien, B. Waeber, G. Parati, J. Staessen, and M. G. Myers, "Blood pressure measuring devices: Recommendations of the European Society of Hypertension," Br. Med. J., vol. 322, no. 7285, pp. 531536, 2001.

[10] R. A. Koestoer, N. Pancasaputra, I. Roihan, and Harinaldi, "A simple calibration methods of relative humidity sensor DHT22 for tropical climates based on Arduino data acquisition system," AIP Conf. Proc., vol. 2062, no. January, 2019.

[11] A. Pudji and M. R. Makruf, "Design of the Digital Pressure Meter with Thermohygrometer," Journal of Information Engineering and Applications, vol. 7, no. 9, pp. 35-39, 2017.

[12] Y. A. Sihombing and S. Listiari, "Detection of air temperature, humidity and soil $\mathrm{pH}$ by using DHT22 and $\mathrm{pH}$ sensor based Arduino nano microcontroller," AIP Conf. Proc., vol. 2221, no. March, 2020.

[13] DW Wulandari, E. Swistoro, and C. Connie, "Effectiveness of aneroid sphygmomanometer modification as a measurement of hydrostatic pressure and its implementation as props," PENDIPA J. Sci. Educ., Vol. 2, no. 1, pp. 82-87, 2018.

[14] A. Türk and A. Hamarat, "Automated Pressure Calibration of Blood Pressure Measuring Device Calibrator to Realize Its Traceability" Med. Meas. Appl. MeMeA 2019 - Symp. Proc., Pp. 1-5, 2019.

[15] RF Muldiani and K. Hadiningrum, "Optimization Tool Practical Law of Thermodynamics," Pros. SNFA (Seminar Nas. Fis. And App., Vol. 3, pp. 237-245, 2018. 